\title{
常時微動計測を用いた伝統木造住宅の簡易最大応答変形評価法の提案

\author{
MAXIMUM RESPONSE EVALUATION OF TRADITIONAL WOODEN HOUSES \\ BASED ON MICROTREMOR MEASUREMENTS
}

\author{
杉野未奈*, 大村早 紀**, 徳岡怜美**, 林 康 裕*** \\ Mina SUGINO, Saki OHMURA, Satomi TOKUOKA \\ and Yasuhiro HAYASHI
}

\begin{abstract}
The objective of this study is to propose the maximum response deformation evaluation method of traditional wooden houses based on microtremor measurements and the amplitude dependency of natural frequency of houses. The equation of the amplitude dependency of natural frequency is based on the results of seismic observation of wooden houses, shaking table tests and static lateral loading tests of wooden frame specimens. To confirm the accuracy of the proposed evaluation method, the maximum response deformation angle on the first story of the full scale specimens of shaking table test is evaluated.
\end{abstract}

Keywords: Traditional Wooden Houses, Microtremor Measurements, Amplitude Dependency of Vibration Characteristics, Natural Frequency, Maximum Response Deformation Angle, Response Spectrum M ethod 伝統木造住宅, 常時微動計測, 動的変形特性, 固有振動数, 最大応答変形角, 応答スペクトル法

\section{1. はじめに}

日本各地に残る伝統木造住宅の中には，耐震診断が実施されてい ない住宅が多数存在するため, 来る大地震に備えて早急に耐震性能 を評価して耐震対策を講じる必要がある。伝統木造住宅の耐震性能 評価においては，限界耐力計算1)はかや時刻歴応答解析2)(珐か等により， 設計用入力地震動に対する最大応答変形が限界変形以下であること を検証することで, 伝統木造住宅の高い変形性能をいかした評価が 可能となる. しかし, それらの評価法は時間やコストを要し, 多数 の住宅に対して実施することは決して容易でない，そこで，本研究 では短時間かつ簡便に建物の固有振動数を容易に得ることができる 常時微動計測に着目し, 常時微動計測から得られる住宅の固有振動 数から, 地震動に対する最大応答変形を求めることを考える.

在来軸組構法を含めた木造住宅の常時微動計測を用いた耐震性能 評価に関して, 下記のような先行研究が挙げられる. 山辺ら²) は, 固 有振動数と木造住宅の築年数や壁量との関係を評価している. 田端 ら $\left.{ }^{4)}, 5\right)$ は, 在来軸組構法の木造住宅について, 常時微動計測で得られ る固有振動数と (財) 日本建築防災協会による「木造住宅の耐震診断 と補強方法」 ${ }^{6)}$ の精密診断法 1 から得られる評点との関係は, 若干の 傾向は見られるがばらつきが大きいことを示している，岩本ら〕は，
在来構法木造 2 階建住宅の常時微動計測から得られた振動特性と地 域性・年代変化・建築面積との平均的傾向を分析している．岡田ら ${ }^{8)}$ は, 木造住宅の常時微動をカオス現象として捉え, 複雑さの程度か ら求めた診断推定值と精密診断法の評点は相関が高いことを示して いる。伝統木造住宅に関しては，新居ら ${ }^{9}$ が京町家に対して，常時 微動計測から得た固有振動数から建物のベースシア係数を簡略的に 推定できることを示している.

これらの研究は, 常時微動計測結果と精密診断法の評点や住宅の 耐力, 建築年等との対応関係に着目した検討を行ったものであり, 地震動に対する最大応答変形を推定しょうとした研究は無かった. そこで筆者らは, 文献 10)にて伝統木造構法による単位軸組架構の振 動台実験結果に基づいて, 固有振動数の振幅依存性を表す動的変形 特性を評価し，限界耐力計算の計算過程である応答スペクトル法 ${ }^{11)}$ に適用することで簡便に伝統木造軸組架構の最大応答変形角が評価 できる可能性を示した。

本論文では，2 階建の伝統木造住宅に適用可能な動的変形特性の 評価式を構築するとともに, 常時微動計測結果から得られる固有振 動数と動的変形特性評価式に基づいた簡便な最大応答変形評価法を 提案する。そして, 既往の実大伝統木造住宅の震動台実験結果に適

\footnotetext{
本稿は文献 34），35）を再構成し，加筆・修正したものである

$*$ 京都大学大学院工学研究科建築学専攻 助教 - 博士 (工学)

** 京都大学大学院工学研究科建築学専攻 修士課程

*** 京都大学大学院工学研究科建築学専攻 教授·工博
}

Assist. Prof., Dept. of Architecture and Architectural Eng., Kyoto Univ., Dr.Eng. Grad. Stud., Dept. of Architecture and Architectural Eng., Kyoto Univ.

Prof., Dept. of Architecture and Architectural Eng., Kyoto Univ., Dr.Eng. 
用することで, 本論文で提案する最大応答変形評価法の精度検証を 行う. 最後に, 入力地震動の加速度応答スペクトルの違いが最大応 答変形や耐震対策に及ぼす影響を, 提案評価法を用いて分析する.

\section{2. 評価法の提案}

本章では, 常時微動計測に基づく, 2 階建の伝統木造住宅の簡易最 大応答変形評価法を構築する. 2.1 節では評価法の定式化について, 2.2 節では 2.1 節で示した評価式に用いるパラメータの設定方法につ いて説明する。

\section{1 定式化}

\section{(A) 等価 1 自由度系への縮約}

2 階建の伝統木造住宅を 2 自由度せん断型質点系でモデル化し, 等 価 1 自由度系に縮約する. 1 階階高 $\mathrm{H}_{1}, 2$ 階階高 $\mathrm{H}_{2}, 1$ 階と 2 階の質 量比 $m_{2} / m_{1}, 1$ 次モードの振幅比 $u_{2} / u_{1}$ を用いれば, 等価 1 自由度系の 等価高さ $\mathrm{H}_{\mathrm{e}}$ は式(1)で表される.

$$
\mathrm{H}_{\mathrm{e}}=\frac{\mathrm{H}_{1}+\left(\mathrm{m}_{2} / \mathrm{m}_{1}\right) \cdot\left(\mathrm{u}_{2} / \mathrm{u}_{1}\right) \cdot\left(\mathrm{H}_{1}+\mathrm{H}_{2}\right)}{1+\left(\mathrm{m}_{2} / \mathrm{m}_{1}\right) \cdot\left(\mathrm{u}_{2} / \mathrm{u}_{1}\right)}
$$

\section{(B) 等価 1 自由度系の最大応答変形の算出}

等価 1 自由度系の最大応答変形 $D_{\text {emax }}$ は, 性能等価加速度応答スペ クトル $\mathrm{S}_{\mathrm{ae}}$ を用いた応答スペクトル法 ${ }^{11)}$ により算出する. $\mathrm{S}_{\mathrm{ae}}$ は式(2) により求める.

$$
S_{\text {ae }}\left[f_{e}[R], R\right] \cdot F_{h}\left[h_{e}[R]\right]=\left(2 \pi f_{e}[R]\right)^{2} R H_{e}
$$

ここで, 例えば, $h_{\mathrm{e}}[R]$ は $h_{\mathrm{e}}$ がR の関数であることを表している. $R$ は 等価 1 自由度系の変形角, $f_{e}$ は等価固有振動数である. $f_{e}$ の $R$ 依存性 を表す動的変形特性 $\mathrm{f}_{\mathrm{e}} / \mathrm{f}_{0}$ を, 3 章で提案する式(3)により表現する.

$$
\mathrm{f}_{\mathrm{e}}[\mathrm{R}] / \mathrm{f}_{0}=\mathrm{b}\left\{\mathrm{a} \log _{10}\left(\mathrm{R} \cdot 10^{3}\right)+1\right\}
$$

ここで, $\mathrm{f}_{0}$ は常時微動計測により求められる固有振動数, $a, b$ はパラ メータである. $F_{h}$ は減衰補正係数で, 文献 12 )による式(4)を用いる.

$$
\mathrm{F}_{\mathrm{h}}\left[\mathrm{h}_{\mathrm{e}}[\mathrm{R}]\right]=(1+0.05 \alpha) /\left(1+\mathrm{h}_{\mathrm{e}}[\mathrm{R}] \cdot \alpha\right)
$$

等価減衰定数 $\mathrm{h}_{\mathrm{e}}$ は, 文献 12$)$ による式 $(5)$ を用いる.

$$
h_{e}[R]=0.05+0.2 \cdot\left\{1-1 /\left(\max \left(\sqrt{R / R_{y}}, 1\right)\right)\right\}
$$

ここで, $R_{y}$ は降伏変形角であり, 本論文では文献 13$)$ と同様に $R_{y}=1 /$ 100rad とする.

入力地震動より, 減衰定数 $5 \%$ の加速度応答スペクトル $\mathrm{S}_{\mathrm{a}}$ を求め, $S_{a}$ と $S_{a e}$ を等值とした式(6)を満たす $R$ より等価 1 自由度系の最大応答 変形角 $R_{\mathrm{emax}}$ を求める.

$$
S_{a e}\left[f_{e}[R], R\right]=S_{a}\left[f_{e}[R]\right]
$$

そして, 等価 1 自由度系の最大応答変形 $\mathrm{D}_{\mathrm{e} \text { max }}$ は式(7)により求まる.

$$
\mathrm{D}_{\mathrm{e} \max }=\mathrm{R}_{\mathrm{e} \text { max }} \cdot \mathrm{H}_{\mathrm{e}}
$$

\section{(C) 各層の最大層間変形角の算出}

$\mathrm{D}_{\mathrm{e} \max }$ より, 1,2 階の最大応答変形 $\mathrm{D}_{1 \max }, \mathrm{D}_{2 \max }$ を式(8)により求める.

$$
D_{I_{\max }}=\beta \mathrm{u}_{1} \mathrm{D}_{\mathrm{e} \max }, \quad \mathrm{D}_{2 \max }=\beta \mathrm{u}_{2} \mathrm{D}_{\mathrm{e} \text { max }}
$$

ここで, $\beta \mathrm{u}_{1}, \beta \mathrm{U}_{2}$ は 1,2 階の 1 次の刺激関数で, 式(9), (10)で表される.

$$
\beta u_{1}=\frac{1+\left(m_{2} / m_{1}\right) \cdot\left(u_{2} / u_{1}\right)}{1+\left(m_{2} / m_{1}\right) \cdot\left(u_{2} / u_{1}\right)^{2}}
$$

$$
\beta u_{2}=\frac{\left(u_{2} / u_{1}\right)+\left(m_{2} / m_{1}\right) \cdot\left(u_{2} / u_{1}\right)^{2}}{1+\left(m_{2} / m_{1}\right) \cdot\left(u_{2} / u_{1}\right)^{2}}
$$

各層の最大層間変形角 $\mathrm{R}_{1 \max }, \mathrm{R}_{2 \max }$ は, 式(11)に示すように $\mathrm{D}_{1 \max }, \mathrm{D}_{2 \max }$ を $\mathrm{H}_{1}, \mathrm{H}_{2}$ で除することにより求められる.

$$
\mathrm{R}_{1_{\max }}=\mathrm{D}_{1_{\max }} / \mathrm{H}_{1}, \quad \mathrm{R}_{2 \max }=\mathrm{D}_{2 \max } / \mathrm{H}_{2}
$$

\section{2 パラメータの設定方法}

\section{(A) $f_{0}, H_{1}, H_{2}$}

固有振動数 $\mathrm{f}_{0}$ は常時微動計測から求めた実測值を用いる. 1 階階高 $\mathrm{H}_{1}, 2$ 階階高 $\mathrm{H}_{2}$ についても実測值を用いる.

(B) $m_{2} / m_{1}, u_{2} / u_{1}$

1 階と 2 階の質量比 $m_{2} / m_{1}, 1$ 次モードの振幅比 $u_{2} / u_{1}$ は, 等価高さ $\mathrm{H}_{\mathrm{e}}, 1,2$ 階の 1 次の刺激関数 $\beta \mathrm{u}_{1}, \beta \mathrm{u}_{2}$ を求めるために用いられる. 住宅 の設計值や評価值があればその值を用いることとし, 無い場合は次 のように評価することを提案する.

$\mathrm{m}_{2} / \mathrm{m}_{1}$ については, 2 階と 1 階の床面積比から略算する. 不明であ る場合は, $m_{2} / m_{1}=1$ とする. $u_{2} / u_{1}$ については, 小屋組, 2 階床, 地盤 の 3 点同時に常時微動計測を実施可能な場合は, 地盤に対する小屋 組, 2 階床のフーリエスペクトル比の 1 次ピークの振幅比を $\mathrm{u}_{2} / \mathrm{u}_{1}$ とみ な寸. 常時微動計測結果から $u_{2} / u_{1}$ を決定できない場合には, 1 階と 2 階の剛性の比 $k_{2} / k_{1}$ と $m_{2} / m_{1}$ から式(12)に示すように 2 自由度せん断型 質点系モデルの固有值より $\mathrm{u}_{2} / \mathrm{u}_{1}$ を求める.

$$
\begin{gathered}
u_{2} / u_{1}=\left\{\left(m_{2} / m_{1}\right) \cdot\left(k_{2} / k_{1}\right)+\left(m_{2} / m_{1}\right)-\left(k_{2} / k_{1}\right)\right. \\
\left.+\sqrt{\left\{\left(m_{2} / m_{1}\right) \cdot\left(k_{2} / k_{1}\right)+\left(m_{2} / m_{1}\right)+\left(k_{2} / k_{1}\right)\right\}^{2}-4\left(m_{2} / m_{1}\right) \cdot\left(k_{2} / k_{1}\right)}\right\} \\
/\left\{2\left(m_{2} / m_{1}\right) \cdot\left(k_{2} / k_{1}\right)\right\}
\end{gathered}
$$

ここで, 1 階と 2 階の全壁長さの比 $\mathrm{L}_{2} / \mathrm{L}_{1}$ を用いて, $\mathrm{k}_{2} / \mathrm{k}_{1} \cong \mathrm{L}_{2} / \mathrm{L}_{1}$ と仮定 する。

\section{（C）地震動および $\alpha$}

地震動は, 減衰定数 $5 \%$ の加速度応答スペクトル $\mathrm{S}_{\mathrm{a}}$ で与えるが, 減 衰補正係数 $\mathrm{F}_{\mathrm{h}}$ を表す式(4)中の $\alpha$ を, 地震動の種類に応じて設定する. $\alpha$ は, パルス性地震動に対しては, 文献 14)を参考に $\alpha=\pi$, パルス性 地震動以外に対しては文献 12) に示される $\alpha=10$ を用いる.

(D) $a, b$

動的変形特性を決定するパラメータ a, b は，3 章の検討に基づいて 決定している. a は $a=-0.4$ とし, b は動的変形特性のばらつきを考慮 して $b=0.5$ または 0.7 とする. 各層の最大層間変形角 $R_{I_{\max }}, R_{2 \max }$ は, $b=0.5$ または 0.7 とした場合の大きい方の值を評価值とする.

\section{3. 動的変形特性の評価}

\section{1 単位軸組架構の動的変形特性}

筆者らは文献 15 ) において, 軸組のみ, 垂壁付き, 差鴨居付きの幅 (柱の心心)約 $1.8 \mathrm{~m}$, 桁と土台との内法高さ約 $2.7 \mathrm{~m}$ の木造軸組架構 (以下, 単位軸組架構) の動的変形特性は, 静的水平加力実験から得 られた復元力特性を基に評価可能であることを示し, それらの単位 軸組架構の動的変形特性評価式を求めた。しかし, 伝統木造住宅の 耐力要素のうち, 全壁が耐力の 5 割程度以上を占める場合が多く ${ }^{16)}$, 全壁の動的変形特性を求めることが伝統木造住宅の最大応答変形を 求める上で重要であると言える，本論文では，簡便な評価法とする 
ため, 主な耐力要素である全壁の壁厚・壁材などの仕様によらない 評価式を構築することを目的として, 仕様の異なる全壁を有する単 位軸組架構の動的変形特性を静的水平加力実験結果に基づいて求め る. 本節では, 文献 17)の土壁を有する全壁 2 体, 乾式パネルを有す る全壁 1 体の計 3 体の単位軸組架構を用いる. 3 体の試験体の諸元を 表 1 に, 試験体の立面図を図1(a), (b)に示寸. なお, 乾式パネルは土 壁下地として用いられる文献 18 ) に示寸製品である.F12\#12 N は, $40 \mathrm{~mm}$ 厚の横貫が 3 本と $15 \mathrm{~mm}$ 厚の縦貫が 1 本入っており, 壁厚は $60 \mathrm{~mm}$ である. F12\#12N を基準として, F12\#12T は壁厚を $200 \mathrm{~mm}$ に 変化させている. F12\#12N, F12\#12T の貫のせいは120mm で, 横貫 の両端は柱に $30 \mathrm{~mm}$ ほど差し込み, 斜めに釷を打ち込んで固定して いる. 貫の接合部仕様は大工ヒアリングに基づいて決定した，F12-12 は, $26 \mathrm{~mm}$ 厚の乾式パネルを横張りで $18 \mathrm{~mm}$ 厚の横貫 4 本および受け 材に片面からコーススレッドを用いて留め付ける．F12-12の貫のせ いは $105 \mathrm{~mm}$ である。

軸組は，柱・桁・土台からなり，柱・土台はスギ，桁はベイマツ である. 柱の芯々間の幅は $1.82 \mathrm{~m}$, 柱径および析と土台間の内法高さ は表 1 に示寸通りである. 試験体の柱頭および柱脚は短ほぞ差しで, 山形プレートVP を両面打ちしており, 柱頭および柱脚にホールダウ ン金物 HD-B10 を設けている.

加力は正負交番漸増 2 回繰り返し加力とし, 目標変形角は, $\pm 1 /$ $200,1 / 120,1 / 100,1 / 75,1 / 50,1 / 30,1 / 20,1 / 15,1 / 10,1 / 8,1 / 6,1 /$ $5,1 / 4 \mathrm{rad}$ とする. 桁を水平に加力したときにロードセルにより計測 した荷重を水平抵抗力 $P$ とする. 桁位置および土台位置で水平変位 を計測し, 土台に対する桁位置の水平変位を内法高さで除した值を 変形角 R とする. 試験体は左右対称であり, 文献 17)に示すように概 ね正負対称な復元力特性である. また, 動的変形特性についても正 負で概敉等しいことを確認している，したがって，本節では正側加 力の結果のみを用いることとする. 水平抵抗力 $P$ - 変形角 R 関係の骨 格曲線( 以下, 復元力特性) において, 変形角 $R$ での割線剛性 $k_{R}$ およ

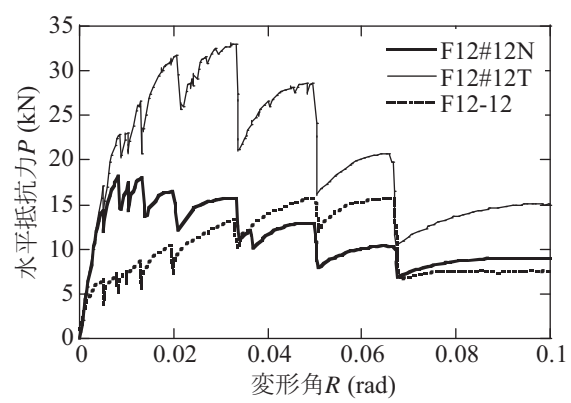

(a) 復元力特性

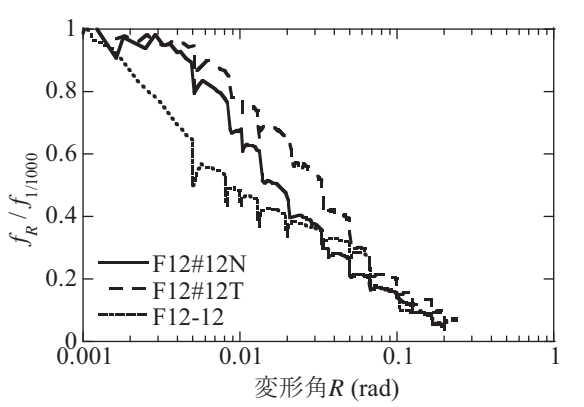

(b) 動的変形特性
図 2 単位軸組架構の復元力特性と動的変形特性
び 1/1000 rad での割線剛性 $k_{1 / 1000}$ から式(13)により動的変形特性 $\mathrm{f}_{\mathrm{R}} / \mathrm{f}_{1 / 1000}$ を算出する.

$$
f_{R} / f_{1 / 1000}=\sqrt{k_{R} / k_{1 / 1000}}
$$

なお, $1 / 1000 \mathrm{rad}$ での水平抵抗力 $\mathrm{P}$ を実験により得られた復元力特性 から線形補完により求め, $k_{1 / 1000}$ を算出寸る. 1/1000 rad を選択した理 由は, 3.2 節で説明する京町家の地震観測では概ね 1/1000 rad までの結 果が得られており, 地震観測で得られた微小変形時の動的変形特性 と静的加力実験で得られた大変形時の動的変形特性との関係を $1 /$ $1000 \mathrm{rad}$ で結びつけることができると考えたためである.

図 2 には, 壁厚, 壁の種類の異なる F12\#12N, F12\#12T, F12-12 の復 元力特性および動的変形特性 $f_{R} / f_{1 / 1000}$ を示すとともに, 表 1 には $k_{1 / 1000}$ を示寸. 表 1 に示寸ように 3 体の $\mathrm{k}_{1 / 1000}$ は概袮しいが, 試験体によっ て水平抵抗力の最大值や復元力特性の形状は大きく異なることが図 2(a)より分かる. また, 1/1000 rad よりも変形が大きくなるにつれて $\mathrm{f}_{\mathrm{R}} / \mathrm{f}_{1 / 1000}$ の試験体間の差が生じるが, $1 / 100 \mathrm{rad}$ を超えて変形が大きくな ると $f_{R} / f_{1 / 1000}$ の差は縮まることが図2(b)より分かる。なお，F12\#12N と壁厚は等しく, 横貫厚は $15 \mathrm{~mm}$ で横貫が壁から露出していない試験

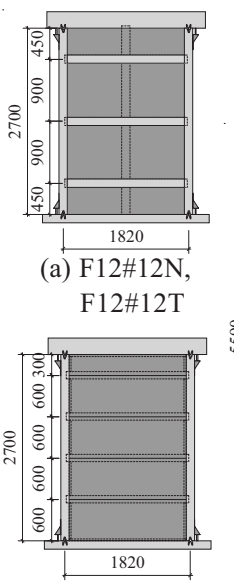

(b) F12-12

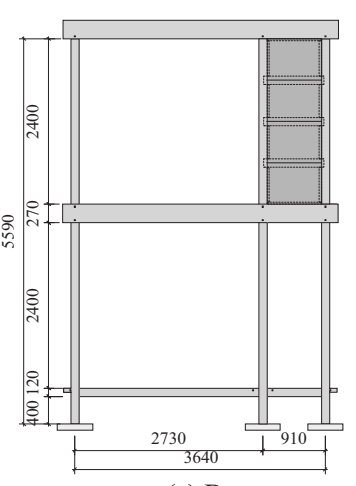

(c) $\mathrm{Bn}$

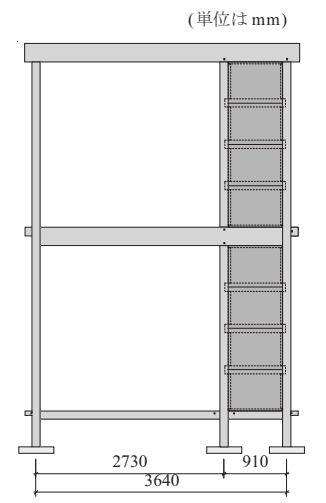

(d) $\mathrm{Cw}$
図 1 単位軸組架構[(a), (b)], 2 階建軸組架構[(c), (d)]の立面図

\section{表 1 単位軸組架構の諸元}

\begin{tabular}{|c|c|c|c|c|c|c|c|c|}
\hline \multirow{2}{*}{ 試験体名 } & \multicolumn{2}{|c|}{ 柱 } & \multicolumn{3}{|c|}{ 壁 } & \multicolumn{2}{|c|}{ 重量 } & 割線剛性 \\
\cline { 2 - 9 } & $\begin{array}{c}\text { 内法高さ } \\
(\mathrm{m})\end{array}$ & 種類 & $\begin{array}{c}\text { 壁厚 } \\
(\mathrm{mm})\end{array}$ & $\begin{array}{c}\text { 横貫厚 } \\
(\mathrm{mm})\end{array}$ & $\begin{array}{c}\text { 試験体 } \\
(\mathrm{kN})\end{array}$ & $\begin{array}{c}\text { 上載 } \\
(\mathrm{kN})\end{array}$ & $\begin{array}{c}\mathrm{k}_{1 / 1000} \\
(\mathrm{kN} / \mathrm{mm})\end{array}$ \\
\hline \hline F12\#12N & 120 & 2.70 & 土壁 & 60 & 40 & 5.0 & 25.7 & 1.37 \\
\hline F12\#12T & 120 & 2.70 & 土壁 & 200 & 40 & 14.2 & 25.7 & 1.39 \\
\hline F12-12 & 120 & 2.70 & 乾式パネル & 26 & 18 & 1.6 & 25.7 & 1.18 \\
\hline
\end{tabular}

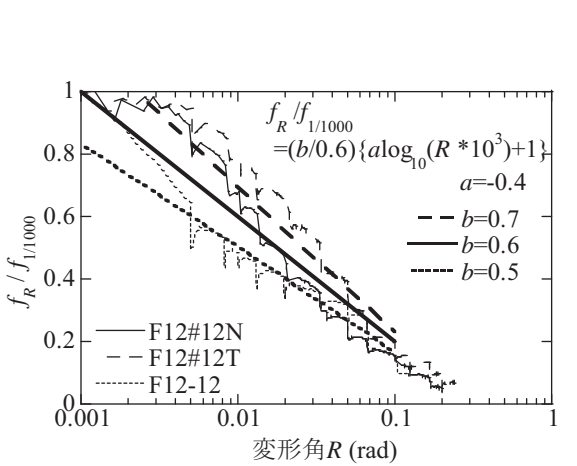

図 3 単位軸組架構の動的変形特性の 実験值と評価式

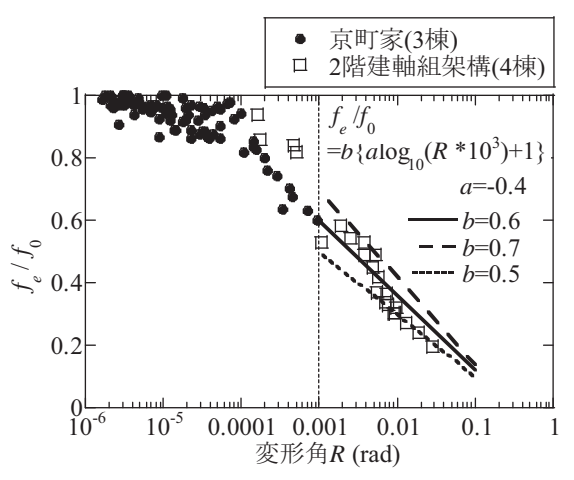

図4 京町家,2 階建軸組架構の動的変形特性 の観測值および実験值と評価式 
体 ${ }^{17)}$ の復元力特性, 動的変形特性は, F $12 \# 12 \mathrm{~N}$ と概衩等しいことを 確認している.

ここで, 図 2(b)に基づいて式(14)に示す $f_{R} / f_{1 / 1000}$ の評価式を考える.

$$
\mathrm{f}_{\mathrm{R}} / \mathrm{f}_{1 / 1000}=(\mathrm{b} / 0.6) \cdot\left\{\mathrm{a} \log _{10}\left(\mathrm{R} \cdot 10^{3}\right)+1\right\}
$$

式(14)の評価式を図 2(b)の実験值と比較した結果を図 3 に示寸. パラ メータaは, 図 3 に示すように式(14)の $f_{R} / f_{1 / 1000}$ が実験結果の傾向を 表すように本論文では $a=-0.4$ とする. 同図に示しているパラメータ b は, $b=0.6$, つまり $(b / 0.6)=1$ を基準とし, $b=0.5,0.7$ についても動的変 形特性のばらつきを評価するために用いる.

\section{2 動的変形特性評価式の構築}

本節では，前節の結果および地震観測記録，振動台実験結果に基 づいて伝統木造住宅の動的変形特性を評価する. 図 4 には, 京町家 3 棟 ${ }^{19}$ )の地震観測および 2 階建軸組架構 4 棟 ${ }^{20}$ の振動台実験より得た 動的变形特性 $\mathrm{f}_{\mathrm{e}} / \mathrm{f}_{0}$ を示寸.

京町家 3 棟のうち 2 棟は京町家の典型的な特徴である細長い平面 形状と通り庭を有しており, 並進となる 1 次の固有振動数は, けた 行方向で $2.2 \mathrm{~Hz}$ および $2.7 \mathrm{~Hz}$, 張り間方向で $5.3 \mathrm{~Hz}$ および $4.6 \mathrm{~Hz}$ であっ た. 1 棟は郊外型の町家であり, けた行・張り間方向を定めることが できなかったため弱軸・強軸方向で $\mathrm{f}_{0}$ を示すと, 弱軸方向で $6.4 \mathrm{~Hz}$, 強軸方向で $7.4 \mathrm{~Hz}$ であった. 京町家の変形角 $\mathrm{R}$ は, 小屋位置で計測さ れた加速度を積分して変位にし, 地表面に対する最大相対変位を求 め, 観測点高さで除して求めている.

2 階建軸組架構は, 通し柱と 1 階壁の有無をパラメータとした Bn, $\mathrm{Bw}, \mathrm{Cn}, \mathrm{Cw} の 4$ 試験体を用いる. 図1(c), (d)に Bn, Cw の立面図を示寸. 2 階梁の両端の接合部において隅柱が 1 階と 2 階を貫く通し柱となる 試験体を C, 隅柱が 1 階と 2 階で分かれている試験体を B とする. 1 階，2 階ともに壁を有して連層壁となる試験体には w , 1 階に壁を有 さない試験体には $\mathrm{n}$ を付す，柱はヒノキであり，天井梁，2 階梁，脚 固, 鼻栓と込栓はベイマツである. 柱脚は礎石立ちとし, 壁は左右 非対称な配置とし， $26 \mathrm{~mm}$ 厚の乾式パネルを横張りで貫および受け材 に片面からコーススレッドを用いて留め付ける。試験体を自立させ るため, 同じ架構を 2 構面を平行に配置し, 小梁, 根太, 構造用合 板(床)および筋交いで結合して一体とする. 天井床, 2 階床, 1 階床 には，それぞれ $19.6 \mathrm{kN}, 19.6 \mathrm{kN}, 4.7 \mathrm{kN}$ のおもりを載せる. 1 次の固有 振動数 $\mathrm{f}_{0}$ は, $\mathrm{Bn}, \mathrm{Bw}, \mathrm{Cn}, \mathrm{Cw}$ の順に $1.3 \mathrm{~Hz}, 2.3 \mathrm{~Hz}, 1.3 \mathrm{~Hz}, 2.5 \mathrm{~Hz}$ であった. 2 階建軸組架構の $\mathrm{R}$ は, 天井床位置の柱脚に対寸る最大相対変位を天 井梁下端から柱脚までの高さで除して求めている.
等価固有振動数 $\mathrm{f}_{\mathrm{e}}$ は, 地震観測, 振動台実験結果ともに, 地動に 対する頂部観測点の加速度フーリエスペクトル比のピーク振動数と 寸る. 京町家 3 棟については, 水平 2 方向の計測結果を 2 つの計測結 果として図 4 に示している.

以上の地震観測記録および振動台実験結果より, $R=1 / 1000 \sim 1 / 10 \mathrm{rad}$ の動的変形特性 $\mathrm{f}_{\mathrm{e}} / \mathrm{f}_{0}$ を式(15)により評価し, 図 4 に併せて示す.

$$
\begin{aligned}
\mathrm{f}_{\mathrm{e}} / \mathrm{f}_{0} & =\left(\mathrm{f}_{1 / 1000} / \mathrm{f}_{0}\right) \cdot\left(\mathrm{f}_{\mathrm{e}} / \mathrm{f}_{1 / 1000}\right) \\
& =b\left\{a \log _{10}\left(\mathrm{R} \cdot 10^{3}\right)+1\right\}
\end{aligned}
$$

なお，式(15)は2 章の式(3)と等しい. 式(15)において, $f_{1 / 1000} / f_{0}$ はb に等しく, 常時微動時に対する $1 / 1000 \mathrm{rad}$ での等価固有振動数の低下 量を表す. 図 4 より, 京町家の等価固有振動数は $1 / 1000 \mathrm{rad}$ のとき 0.6 倍程度に低下しているため, 本論文では $b=0.6$ とともに動的変形 特性のばらつきを考慮するために, $b=0.5,0.7$ について検討する。一 方, $f_{e} / f_{1 / 1000}$ は, 静的水平加力実験から求めた動的変形特性である式 (14) と $f_{e}=f_{R}$ として等しいと見なし, 本論文では前節で定めた $a=-0.4$ を 用いる。

\section{4. 評価法の精度検証}

\section{1 ベースシア係数}

本節では, 3 章で構築した動的変形特性からベースシア係数 $\mathrm{C}_{b}$ - 固 有振動数 $\mathrm{f}_{0}$ 関係を求め, 既往の研究 ${ }^{9}$ により提案されている降伏ベー スシア係数 $C_{y}-f_{0}$ 関係と比較を行うことで, 本研究で提案した動的変 形特性と既往の研究結果との関係を把握する。まず，等価 1 自由度 せん断型質点系モデルを考え, 2 章の式(3) (3 章の式(15) と等しい) で示した動的変形特性 $\mathrm{f}_{\mathrm{e}} / \mathrm{f}_{0}$ からベースシア係数 $\mathrm{C}_{\mathrm{b}}$ を求める. 等価 1 自由度系の変形角は式(3)の $\mathrm{R}$ と等しいと寸る. せん断力を総重量で 除した值をべースシア係数 $C_{b}$ と定義すれば， $C_{b}$ は式(16) となる.

$$
\mathrm{C}_{\mathrm{b}}=\mu\left(2 \pi \mathrm{f}_{\mathrm{e}}\right)^{2} \mathrm{RH}_{\mathrm{e}} / \mathrm{g}
$$

ここで, $\mathrm{g}$ は重力加速度, $\mathrm{H}_{\mathrm{e}}$ は式(1)に示寸等価高さ, $\mu$ は式(17)に 示す有効質量比である。

$$
\mu=\frac{m_{e}}{\left(m_{1}+m_{2}\right)}=\frac{\left\{1+\left(m_{2} / m_{1}\right) \cdot\left(u_{2} / u_{1}\right)\right\}^{2}}{\left\{1+\left(m_{2} / m_{1}\right) \cdot\left(u_{2} / u_{1}\right)^{2}\right\} \cdot\left(1+m_{2} / m_{1}\right)}
$$

ここで， $\mathrm{m}_{\mathrm{e}}$ は有効質量である. 図 5 では, 固有振動数 $\mathrm{f}_{0}=3 \mathrm{~Hz}, \mu=0.9$, $\mathrm{H}_{\mathrm{e}}=4.5 \mathrm{~m}$ の等価 1 自由度系について, 式(3)を式(16)に代入して求め た $C_{b}$ を示す. ただし, 式(3)に示寸 $f_{e} / f_{0}$ のパラメータ b は $b=0.5,0.6$, 0.7 の 3 ケースを示している. ベースシア係数 $\mathrm{C}_{b}$ が最大值 $\mathrm{C}_{\mathrm{b} \max }$ となる

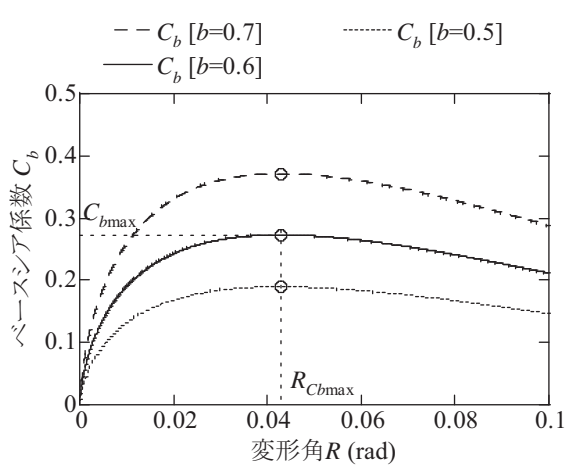

図 5 ベースシア係数 $C_{b^{-}}$変形角 $R$ 関係 $\left[f_{0}=3 \mathrm{~Hz}, \mu=0.9, H_{e}=4.5 \mathrm{~m}, a=-0.4\right]$

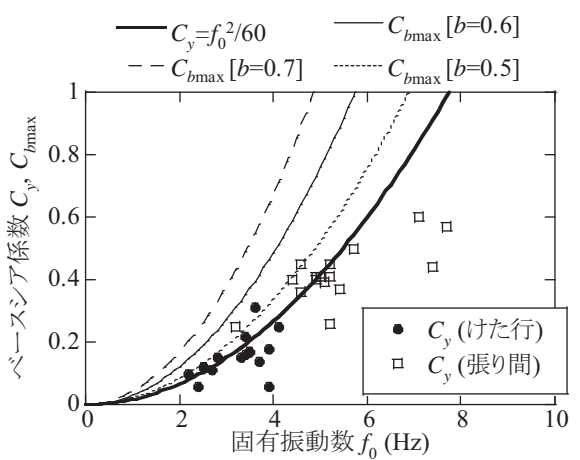

図 6 ベースシア係数 $C_{y}, C_{b \max }$ - 固有振動数 $f_{0}$ 関係

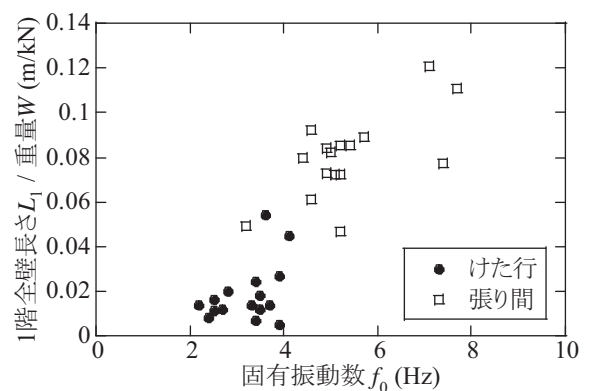

図 71 階全壁長さ $L_{1} /$ 重量 $W$ - 固有振動数 $f_{0}$ 関係 
ときの変形角 $R_{C b \max }$ は式(3), (16)より式(18)となる.

$$
R_{C b \max }=10^{-(3+1 / a)} / \mathrm{e}^{2}
$$

ここで, e は自然対数の底である. 式(18)から分かるように, $R_{c b \max }$ はaのみによって決定される。式(3), (18)を式(16)に代入すると $C_{b \max }$ が式(19)のように求まる.

$$
\mathrm{C}_{\mathrm{b} \max }=\mathrm{f}_{0}{ }^{2} \cdot\left(\mu \mathrm{H}_{\mathrm{e}} / \mathrm{g}\right) \cdot\left\{4 \pi \mathrm{ab}\left(\log _{10} \mathrm{e}\right) / \mathrm{e}\right\}^{2} \cdot 10^{-(3+1 / a)}
$$

一方, 文献 9) では, 京町家 6 棟の常時微動計測から得た $f_{0}$ と降伏 ベースシア係数 $C_{\mathrm{y}}$ との関係を回帰することにより評価式(20)を提案 している.

$$
C_{y}=f_{0}^{2} / 60
$$

ただし， $C_{y}$ は, 各構造要素の復元力特性 ${ }^{1)}$ の累加により 1 階の復元力 特性を求め, 1 階の変形角が $1 / 30 \mathrm{rad}$ のきの復元力を総重量で除し て算出している. なお, 総重量は 1 階階高の $1 / 2$ の高さより上部の重 量として算定している.

$\mu=0.9, \mathrm{H}_{\mathrm{e}}=4.5 \mathrm{~m}, \mathrm{a}=-0.4, \mathrm{~b}=0.5,0.6,0.7$ とした $\mathrm{C}_{b_{\max }-} \mathrm{f}_{0}$ 関係 $\left[\right.$ 式(19)]と $\mathrm{C}_{\mathrm{y}^{-}}$ $\mathrm{f}_{0}$ 関係 $[$ 式(20)] を比較して図 6 に示す. 同図には, 文献 21$)$ に掲載さ れている京町家 19 棟のうち，1 階の全壁長さが不明である住宅およ び平屋をのぞいた 16 棟のけた行, 張り間方向の計 32 点の $\mathrm{C}_{\mathrm{y}^{-}} \mathrm{f}_{0}$ 関係 を示している. なお， $C_{y}$ の算出方法は上記で説明した文献 9) と同様 である. 図6より， $f_{0}$ が等しいとき， $C_{b \max }$ はbによって $C_{y}$ の約 1.3 倍 から 2.5 倍となることが分かる. 式(20)のC $\mathrm{y}$ は文献 1)で与えられる 設計值であるのに対し, 式(19)の $C_{b \max }$ は 3 章に示したように実験值 から算出した值であるために, $C_{b \max }$ は $C_{y}$ よりも大きくなる傾向にあ る.

図 7 には, 文献 21 )の京町家 16 棟のけた行または張り間方向の 1 階の全壁長さ $\mathrm{L}_{1}$ を 1 階階高の半分以上の重量 $W$ で除した $\mathrm{L}_{1} / \mathrm{W}$ と $\mathrm{f}_{0}$ の関 係を示す。同図より, $\mathrm{L}_{1} / \mathrm{W}$ と $\mathrm{f}_{0}$ には相関があり, 壁量を増やせば $\mathrm{f}_{0}$ が 増加することが分かる。

\section{2 震動台実験結果に基づく精度検証}

本論文で提案する最大応答変形評価法の精度検証として, 文献 22)27 )のE-ディフェンスで行われた伝統木造住宅の実大試験体の震動 台実験結果を評価する.

\section{2 .1 震動台実験の概要}

本項では，精度検証に用いる震動台実験結果について，各試験体 の特徵, 評価に用いる入力地震動, 損傷状況を文献 22)-27)に基づい て, 以下,(A)-(C)にまとめる. 試験体は, 都市近郊型試験体 22), 23), 地 方型試験体 ${ }^{23)}$, 24), 新築京町家試験体 $\left.{ }^{25)} 27\right)$ の 3 体であり, すべて新築の 実大総 2 階建である.

\section{(A) 都市近郊型試験体 22)，23)}

\section{[ 試験体の特徴]}

平面寸法は $10.91 \times 5.45 \mathrm{~m}$ であり, 後述 $(\mathrm{B})$ の地方型試験体に比べ て柱梁などの軸組断面が小さい。長手方向がけた行方向であり, 短 手方向が張り間方向である. 1 階柱脚は, 足固めに対して「柱勝ち」, 土台に対して「土台勝ち」である。土台はアンカーボルトで固定さ れており，水平・上下の移動が拘束されている. 足固めは長尺ボル トで固定されているが，足固めが $150 \mathrm{~mm}$ 浮上ったときのみホールダ ウン金物の軸力が働く仕様となっている、壁は土壁であり，壁厚は $80 \mathrm{~mm}$, 半柱に取付く土壁の壁厚は $65 \mathrm{~mm}$ である. 横貫の断面はせい $115 \mathrm{~mm}$, 幅 $27 \mathrm{~mm}$ であり, 4 段を標準として壁の中に設置されている.
貫と柱との接合部は, 開口部脇は柱途中で止めるが，他は通し貫と する. 土壁は文献 28 ) に準拠した施工がなされている. なお，試験体 には, 階段や二次部材, 非構造部材は使用されていない. 2 質点に置 換した地震力算定重量は, 1 層で $182.12 \mathrm{kN}, 2$ 層で $143.47 \mathrm{kN}$ である. [ 評価に用いる入力地震動]

日本建築センター模擬波 ${ }^{29}$ (基盤波)の BCJ-L2 の変位振幅 $100 \%$ の 水平 1 方向毎の結果を用いる. また，1995 年兵庫県南部地震の神戸 海洋気象台 ${ }^{30)}$ の 3 軸方向の変位振幅 $100 \%$ (以下, JMA 神戸) の 2 回加 振しているうち 1 回目の入力結果を用いる. 長手方向が NS 方向, 短 手方向が $\mathrm{EW}$ 方向となるように入力されているため, 本論文では長 手方向は NS 成分のみ, 短手方向は EW 成分のみとして方向毎に評価 する。

\section{[ 損傷状況]}

BCJ-L2 波 $100 \%$ 加振時には，1 階壁表面に貫に沿って土壁のひび割 れが発生しているが，軸組の損傷は見受けられなかった。また，柱 脚の浮上りが数 $\mathrm{mm}$ 生じた. JMA 神戸加振時には, 多くの土壁や柱 に剥落, ひび割れが生じ, 最大で約 $116 \mathrm{~mm}$ の柱脚の浮上りが生じた.

(B) 地方型試験体 23), 24)

\section{[ 試験体の特徵]}

平面寸法は $11.82 \times 5.91 \mathrm{~m}$ であり, (A)の都市近郊型試験体に比べ て柱梁などの軸組断面が大きい。長手方向がけた行方向であり，短 手方向が張り間方向である. 1 階柱脚は, 地伏土台に対して「柱勝ち」 で，礎石の上に載せており，水平移動は鋼製のダボで拘束されてい

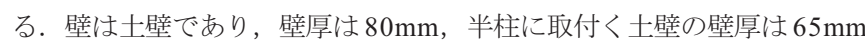
である、横貫の断面はせい $105 \mathrm{~mm}$ ，幅 $15 \mathrm{~mm}$ であり，1階は 4 段， 2 階は 3 段が壁の中に設置されている。貫と柱との接合部は，開口部 脇は柱途中で止めるが，他は通し貫とする. 土壁は文献 28)に準拠し た施工がなされている。 なお, 非構造部材については(A) と同様であ る. 2 質点に置換した地震力算定重量は，1層で $207.43 \mathrm{kN}, 2$ 層で $173.86 \mathrm{kN}$ である。

[評価に用いる入力地震動] (A) と同様である.

[ 損傷状況]

BCJ-L2 波 $100 \%$ 加振時には，土壁のひび割れ，剥落および通し柱 1 本にひび割れが生じた。また，柱脚の浮上りが生じた。JMA 神戸 加振時には, 多くの土壁や柱に剥落, ひび割れが生じ, 柱脚の浮上 りが生じた。

\section{(C) 新築京町家試験体 25) 27)}

\section{[ 試験体の特徵]}

平面寸法は $12.87 \times 6.14 \mathrm{~m}$ である. 長手方向が張り間方向であり， 短手方向がけた行方向である. 1 階柱脚は, 礎石立ち基礎とし, 通し 柱間を足固めで繋いでいる．短手方向の 2 箇所にはしご型フレーム が設けられている. 1 階は $65 \mathrm{~mm}$ 厚の土壁である. 横貫の断面はせい $105 \mathrm{~mm}$ ，幅 $15 \mathrm{~mm}$ であり，3 段が壁の中に設置されている．2 階は乾 式パネル ${ }^{18)}$ 栈下地構法横両面張り中塗り仕上げである. 2 質点に置換 した地震力算定重量は，1 層で $144.8 \mathrm{kN} ， 2$ 層で $143.9 \mathrm{kN}$ である.

[ 評価に用いる入力地震動]

BCJ-L2 は，最大地動加速度が $4.0 \mathrm{~m} / \mathrm{s}^{2}$ に調整された入力地震動を用 いる.JMA 神戸は(A) と同様である.

[ 損傷状況]

JMA 神戸加振前までは，壁仕上げのひび割れ等軽微な損傷であっ 
た. JMA 神戸加振では, 柱脚が移動し, 礎石周囲を固定していた金 物によって通し柱脚部の折損が生じた他, 漆喰などの剥離やひび割 れの増大が確認された。ただし, 壁全体が剥落するなどの大きな損 傷はなかった。 なお, 同加振で試験体が長手方向に約 $230 \mathrm{~mm}$, 短手 方向に約 $100 \mathrm{~mm}$ 移動した.

\section{2 .2 評価方法}

試験体の 1 階最大層間変形角 $R_{1 \text { max }}$ を評価するために, 文献 22)-27) に基づき表 2 のようにモデル化する．各パラメータは 2.2 節に基づい て設定している， $f_{0}$ は論文に記載されている常時微動計測結果から得 られた実験前の固有振動数である. $\mathrm{H}_{1}, \mathrm{H}_{2}$ は 1,2 階階高であり, 質 量比 $m_{2} / m_{1}$ は, 床面積比から $m_{2} / m_{1}=1$ と略算する. 1 次モードの振幅 比 $u_{2} / u_{1}$ は, 1 階と 2 階の長手, 短手方向それぞれの 1 階と 2 階の全
壁長さの比 $\mathrm{L}_{2} / \mathrm{L}_{1}$ を剛性比 $\mathrm{k}_{2} / \mathrm{k}_{1}$ と等しいと見なし, 1 階と 2 階の質量 比 $m_{2} / m_{1}$ と $k_{2} / k_{1}$ を用いて 2 自由度せん断型質点系モデルの固有值を 求めている. 等価高さ $\mathrm{H}_{\mathrm{e}}$ は式(1)で求める. 式(3)の動的変形特性評 価式は， $a=-0.4$ は一定として, $b=0.5,0.6,0.7$ と寸る. $F_{h}$ の $\alpha$ は, JMA 神戸では $\alpha=\pi, \mathrm{BCJ}-\mathrm{L} 2$ では $\alpha=10$ を用いる.

本論文での評価に用いる BCJ-L2, JMA 神戸の加速度波形は, 都市 近郊型試験体, 地方型試験体については, E-ディフェンス アーカイ ブ(ASEBI $)^{31)}$ に公開されている震動台上で得られた各加振回の加速度 波形とする。しかし, 新築京町家試験体の実験結果は公開されてい ないため, BCJ-L2 は一般財団法人 日本建築センターで提供されてい る加速度波形 ${ }^{29)}, \mathrm{JMA}$ 神戸は観測波形 ${ }^{30)}$ を用いる。

文献 29), 30)の BCJ-L2, JMA 神戸 NS の加速度の時刻歴波形を図 8 に,

表 2 実大試験体のモデルの諸元

\begin{tabular}{|c|c|c|c|c|c|c|c|c|c|c|c|}
\hline & & $\begin{array}{l}f_{0} \\
(\mathrm{~Hz})\end{array}$ & $\begin{array}{l}\mathrm{H}_{1} \\
(\mathrm{~m})\end{array}$ & $\begin{array}{l}\mathrm{H}_{2} \\
\text { (m) }\end{array}$ & $\mathrm{m}_{2} / \mathrm{m}_{1}$ & $\mathrm{~L}_{2} / \mathrm{L}_{1}$ & $\mathrm{u}_{2} / \mathrm{u}_{1}$ & $\begin{array}{l}\mathrm{H}_{\mathrm{e}} \\
\text { (m) }\end{array}$ & $\begin{array}{l}\text { JMA神戸 } \\
\text { 入力方向 }\end{array}$ & $\begin{array}{c}\text { BCJ-L2 } \\
\text { PGA }\left(\mathrm{m} / \mathrm{s}^{2}\right)\end{array}$ & 文献 \\
\hline \multirow{2}{*}{$\begin{array}{l}\text { 都市 } \\
\text { 近郊型 }\end{array}$} & 長手 & 3.3 & \multirow{2}{*}{2.76} & \multirow{2}{*}{2.60} & \multirow{7}{*}{1.0} & 0.82 & 1.78 & 4.42 & NS & \multirow{4}{*}{3.56} & 22), \\
\hline & 短手 & 3.0 & & & & 0.94 & 1.66 & 4.38 & EW & & 23) \\
\hline \multirow{2}{*}{ 地方型 } & 長手 & 2.8 & \multirow{2}{*}{2.85} & \multirow{2}{*}{2.75} & & 0.76 & 1.85 & 4.63 & NS & & 23), \\
\hline & 短手 & 2.6 & & & & 0.94 & 1.66 & 4.57 & EW & & 24) \\
\hline \multirow{2}{*}{$\begin{array}{l}\text { 新築 } \\
\text { 京町家 }\end{array}$} & 長手 & 4.7 & \multirow{2}{*}{2.75} & \multirow{2}{*}{2.80} & & 0.94 & 1.66 & 4.50 & NS & \multirow{2}{*}{4.00} & 25) \\
\hline & 短手 & 2.5 & & & & 1.21 & 1.49 & 4.43 & EW & & 27) \\
\hline 単純化 & - & - & 2.70 & 2.70 & & - & 2.00 & 4.50 & - & - & - \\
\hline
\end{tabular}

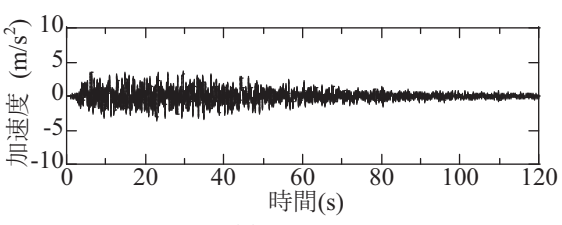

(a) BCJ-L2

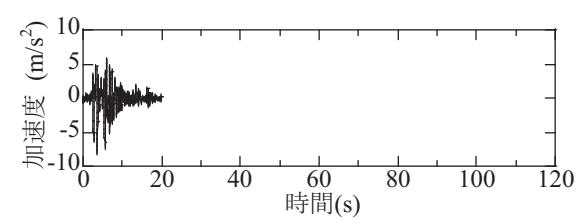

(b) JMA 神戸 NS

図 8 加速度の時刻歴波形

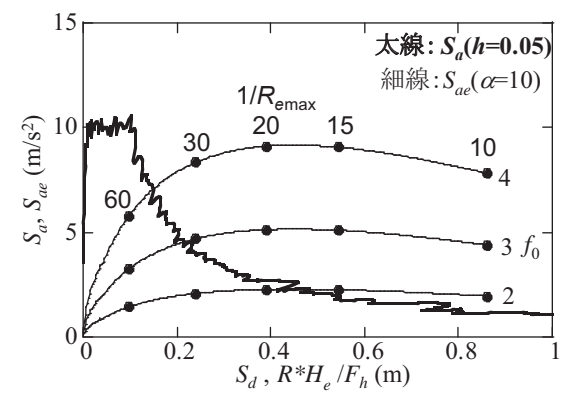

(a) BCJ-L2

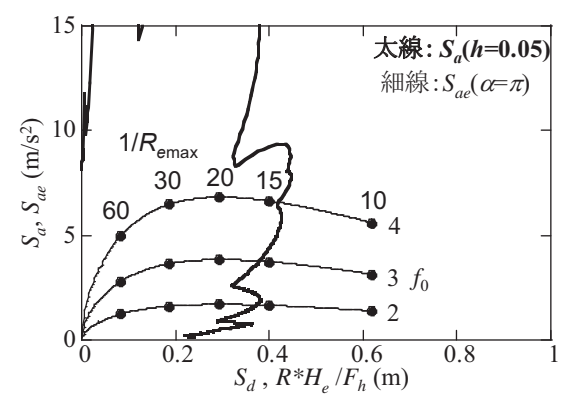

(b) JMA 神戸 NS

図 $9 S_{a}-S_{d}$ 関係, $S_{a e}-R^{\star} H_{e} / F_{h}$ 関係 $\left[m_{2} / m_{1},=1, u_{2} / u_{1}=2, H_{1}=H_{2}=2.7 \mathrm{~m}, b=0.6\right]$

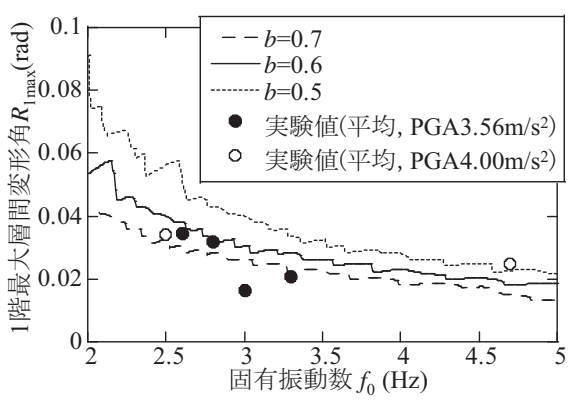

(a) BCJ-L2

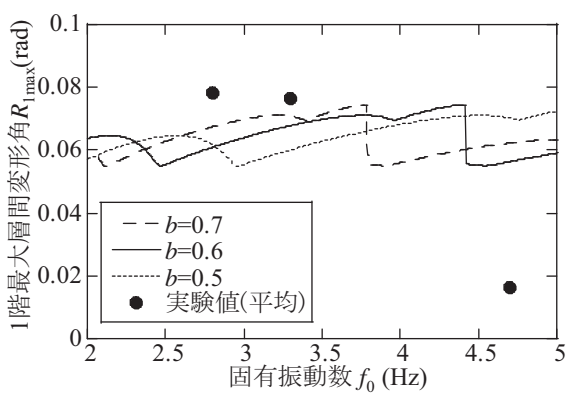

(b) JMA 神戸 NS

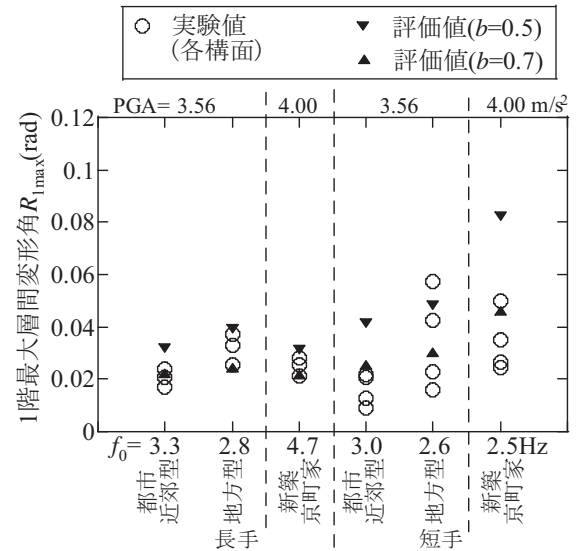

(a) BCJ-L2

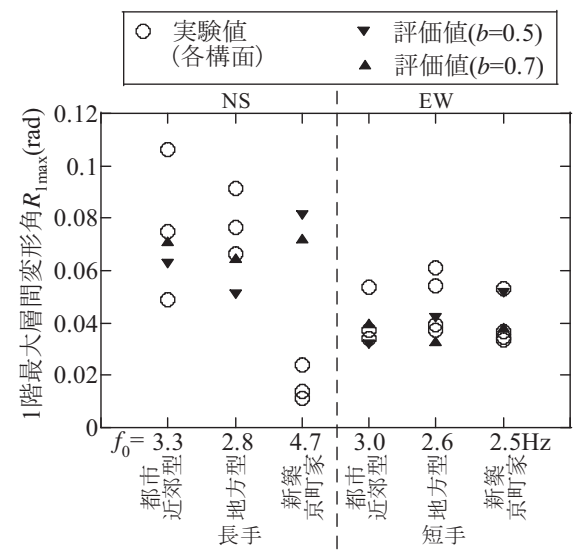

(b) JMA 神戸

図 10 実大試験体の $R_{1 \max }$ の評価結果 $\left[H_{1}, H_{2}:\right.$ 実験値, $m_{2} / m_{1}, u_{2} / u_{1}$ : 評価値 $]$

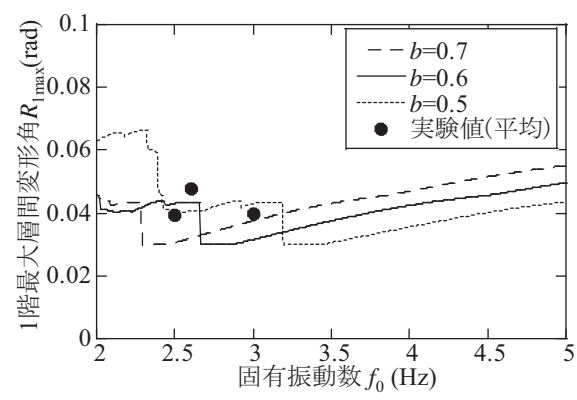

(c) JMA 神戸 $\mathrm{EW}$

図 11 固有振動数 $f_{0}$ の建物モデルの 1 階最大層間変形角 $R_{1 \max }\left[m_{2} / m_{1},=1, u_{2} / u_{1}=2, H_{1}=H_{2}=2.7 \mathrm{~m}\right]$ 
減衰定数 $5 \%$ の加速度応答スペクトル $\mathrm{S}_{\mathrm{a}}$ - 変位応答スペクトル $\mathrm{S}_{\mathrm{d}}$ 関係 を図 9 に示寸. 同図には, $m_{2} / m_{1},=1, u_{2} / u_{1}=2, H_{1}=H_{2}=2.7 m, f_{0}=2,3,4 \mathrm{~Hz}$ の等 価 1 自由度系の性能等価加速度応答スペクトル $S_{a_{e}}$ 変形 $R * H_{e} / F_{h}$ 関係 を併せて示寸．なお，動的変形特性評価式は， $a=-0.4, b=0.6$ とし, $F_{h}$ の $\alpha$ は, BCJ-L2 で $\alpha=10, J M A$ 神戸 NS で $\alpha=\pi$ としている. $\mathrm{S}_{\mathrm{ae}}-\mathrm{R} * \mathrm{H}_{\mathrm{e}} / \mathrm{F}_{\mathrm{h}}$ 関 係には, 等価 1 自由度系の最大応答変形 $R_{\text {emax }}$ の逆数 $1 / R_{\text {emax }}$ の代表值 を併せて示しており, $S_{\mathrm{a}}-S_{\mathrm{d}}$ 関係と $S_{\mathrm{ae}}-\mathrm{R} * \mathrm{H}_{\mathrm{e}} / \mathrm{F}_{\mathrm{h}}$ 関係の交点での横軸に, $F_{h}$ を乗じることで最大応答変形が求まることに注意されたい.

\subsection{3 評価結果}

本項では, 最大応答変形評価法の評価結果を入力地震動ごとに実 験結果と比較することにより分析する. 全ての試験体において, 長 手方向で 3 構面, 短手方向で 4 構面それぞれに 1 階最大層間変形角 $\mathrm{R}_{{ }_{\text {max }}}$ の実験值が存在する. 図 10 には, 長手, 短手それぞれの方向につい て, $\mathrm{R}_{1 \text { max }}$ の各構面の実験值と式(3)の動的変形特性評価式で $\mathrm{a}=-0.4$, $b=0.5,0.7$ のときの評価值を比較して示す. 図 11 には, $\mathrm{f}_{0}$ を変化させ た $\mathrm{m}_{2} / \mathrm{m}_{1}=1, \mathrm{u}_{2} / \mathrm{u}_{1}=2, \mathrm{H}_{1}=\mathrm{H}_{2}=2.7 \mathrm{~m}$ である 2 自由度せん断型質点系モデル の文献 29), 30)の BCJ-L2 ( PGA=3.56 $\left./ \mathrm{s}^{2}\right)$ および JMA 神戸 NS, EW に対 する $R_{1 \max }$ を示す。同図には, 図 10 に示寸各構面の実験值 $R_{1 \max }$ の平均 值を併せて示す, ただし, 図 11(a)にはBCJ-L2 $\left(\mathrm{PGA}=4.00 \mathrm{~m} / \mathrm{s}^{2}\right)$ に対す る各構面の実験值 $\mathrm{R}_{1 \max }$ の平均値についても参考に示している.

\section{(A) BCJ-L2}

図 10(a)より, $b=0.7$ のとき, $R_{1 \text { max }}$ の評価值は, 概敉各構面の実験值 の平均程度以上で評価できていることが分かる. また， $b=0.5$ のとき の $\mathrm{R}_{1 \text { max }}$ の評価值は, 各構面の実験值以上であり, 最大で $0.03 \mathrm{rad}$ 程度 大きく評価している. なお, 地方型試験体の短手方向で構面ごとの 実験值に差が大きい理由は，㨭れ振動が生じていたためと文献 23)で は考察されている. 図11(a)より, b を大きくすると $\mathrm{R}_{1 \text { max }}$ の評価值が 小さくなり， $\mathrm{f}_{0}$ を大きくすると $\mathrm{R}_{1 \max }$ の評価值は小さくなることが分 かる.

\section{(B) JMA 神戸}

図 $10(\mathrm{~b})$ より, $\mathrm{R}_{1 \max }$ の評価值はb によって大きく変わらず最大で $0.02 \mathrm{rad}$ 程度の差である. また, 各構面の実駼值に差があるものの, $\mathrm{R}_{\mathrm{Imax}}$ の評価值は, 新築京町家試験体の長手方向を除いて実験值を概㸚評 価できていることが分かる. 新築京町家試験体の長手方向の $R_{1 \text { max }}$ の 実験值が他の試験体に比べて小さく, 過大評価となった理由は, 同 加振回において礎石立ちである柱脚が滑動し, 層間変形が大きく生 じなかったためと考えられる. $\mathrm{f}_{0}$ が大きくなるとベースシア係数の最 大值 $\mathrm{C}_{\mathrm{b} \max }$ も大きくなり, $\mathrm{C}_{\mathrm{b} \max }$ が静止摩擦係数を上回ることで柱脚の 滑動が生じる可能性があるため, $\mathrm{R}_{1 \text { max }}$ の評価の際には注意が必要で あると言える. 都市近郊型試験体では構面によって $\mathrm{R}_{1 \text { max }}$ の実験值が 大きく異なっているが，同加振では捩れ振動成分が多く含まれてい ることが確認されている ${ }^{22)}$. 本論文で提案する評価法は, 構面間の $\mathrm{R}_{1 \text { max }}$ の違いを評価することはできない. しかし, 文献1)のように建 物の復元力特性を各構造要素の累加により詳細に求めて限界耐力計 算を行っても, 各構面ごとの $\mathrm{R}_{1 \text { max }}$ を定量的に評価することはできな いため, 各構造要素を確認することなく容易に $\mathrm{R}_{1 \text { max }}$ を求めることが できる本評価法には有用性がある。図11(b), (c)に示すように, JMA 神戸を入力した場合, BCJ-L2 と異なり b が大きいほど $\mathrm{R}_{1 \text { max }}$ の評価值 が小さくなるとは限らない. また, $\mathrm{f}_{0}$ によって $\mathrm{R}_{1 \text { max }}$ は大きく変化せ ず， $\mathrm{f}_{0}$ が大きくなると $\mathrm{R}_{1 \max }$ も大きくなる場合がある.

\section{5. 評価例}

本章では，本論文で提案した簡易最大応答変形評価法を用いて， 単純化したモデルに対して数值解析を行い, 加速度応答スペクトル の違いが伝統木造住宅の最大応答変形および而震対策に及ぼす影響 を分析する.

\section{1 入力地震動}

下記(A) (C)に示す, 建築基準法により規定される手法により算出 された地表面での加速度応答スペクトル（以下, 告示スペクトル), 内陸地凯内地震の震源近傍で得られた観測地震動（以下，パルス性 地震動), パルス性地震動を単純化したRicker wavelet の三種類の入力 地震動を用いる. 三種類の入力地震動について, 減衰定数 $5 \%$ の加速 度応答スペクトル $S_{a}$ - 変位応答スペクトル $S_{d}$ 関係および等価 1 自由度 系の性能等価加速度応答スペクトル $\mathrm{S}_{\mathrm{ae}}$ - 変形 $\mathrm{R} * \mathrm{H}_{\mathrm{e}} / \mathrm{F}_{\mathrm{h}}$ 関係を図 12 に示 す. なお, 式(3)の動的変形特性評価式のパラメータは $a=-0.4, \quad b=0.6$ とする. $\mathrm{F}_{\mathrm{h}}$ の $\alpha$ は告示スペクトルで $\alpha=10$, パルス性地震動, Ricker wavelet で $\alpha=\pi$ としている.

(A) 告示スペクトル

建築基準法により規定される手法に基づき, 地表面での加速度応 答スペクトルを求める. 減衰定数 $5 \%$ に対応寸る解放工学的基盤にお ける標準加速度応答スペクトルに, 表層地盤による加速度増幅率, 加速度応答スペクトルの調整係数を乗じて求める. 表層地盤による 加速度増幅率は, 簡略法の第 1 種地盤および第 2 種地盤を用いる. そ れとともに，林ほか32)が提案する略算スペクトルを用いる. 略算ス ペクトルの表層地盤による加速度増幅率は, 地盤を半無限 2 層地盤 と考え, 表層地盤の 2 種類の土質種別, 安全限界と損傷限界に対し て, 4 種類提案されている. 本論文では, 表層地盤を粘性土, 弹性時 インピーダンス比を 0.3 , 弾性時地盤 1 次周期を $0.5 \mathrm{~s}$ として求めた結 果を用いる. 加速度応答スペクトルの調整係数は, 建築物の階数及 び等価周期に応じた調整係数 $p$ は $p=0.85$ とする. 建築物の有効質量 比に応じた調整係数 $q$ は $q=1.0$ とする.

\section{（B）パルス性地震動}

パルス性地震動として, 近年発生した内陸地殼内地震の震源近傍 で得られた 4 つの観測地震動を用いる. 表 3 に示寸 1995 年兵庫県南 部地震の神戸海洋気象台の NS 方向（以下, JMA 神戸 NS）およびJR 鷹取駅の NS 方向（以下, 鷹取 NS), 2004 年新潟県中越地震の川口町 役場の EW 方向 (以下, JMA 川口EW), 2007 年新潟県中越沖地震の 刈羽村の NS 方向（刈羽村 NS）の観測地震動を用いる. 表 3 には, $h=0.05$ の擬似速度応答スペクトルが最大值をとるときの周期をパルス周期 $T_{p}$, 固有周期 $T=20 \mathrm{~s}$, 減衰定数 $h=0.707$ の 1 自由度系の速度応答の逆位 相として求めた地動速度の最大值を PGV として算出した結果を示し ている.

\section{(C) Ricker wavelet}

パルス性地震動の卓越周期, 振幅が変化することによる影響を考 察するためにRicker wavelet ${ }^{33)}$ を入力地震動として用いる. パルス周期 $\mathrm{T}_{\mathrm{p}}$ は, Ricker wavelet の加速度波形のフーリエ変換の極大值をとるとき の周期であり， $V_{p}$ は速度の最大值である. Ricker wavelet の時刻歴波形 を図 13 に示す. 本論文では, $T_{p}=0.5,1.0,2.0 \mathrm{~s}, \mathrm{~V}_{\mathrm{p}}=0.50,0.75,1.00 \mathrm{~m} / \mathrm{s}$ で変 化させて検討する.

\section{2 評価方法}

建物モデルの諸元は表 2 に示寸単純化モデルであり, $\mathrm{H}_{1}=\mathrm{H}_{2}=2.7 \mathrm{~m}$, 
$\mathrm{m}_{2} / \mathrm{m}_{1}=1, \mathrm{u}_{2} / \mathrm{u}_{1}=2$ とする. そのとき, $\mathrm{H}_{\mathrm{e}}=4.5 \mathrm{~m}, \mu=0.9$ となる. $\mathrm{f}_{0}$ は $2 \sim 5 \mathrm{~Hz}$ で変化させる. 式(3)の動的変形特性評価式の a は $a=-0.4$ とし, b は 考察を容易にするために $b=0.6$ とする. $F_{h}$ の $\alpha$ は, パルス性地震動お よびRicker wavelet では $\alpha=\pi$, 告示スペクトルでは $\alpha=10$ を用いる.

\section{3 評価結果}

1 階最大層間変形角 $\mathrm{R}_{1 \max }$ の評価結果を図 14 に示し, 入力地震動ご との結果を下記 $(A) \sim(C)$ にて分析する.

\section{(A) 告示スペクトル}

表層地盤による加速度増幅率が異なる告示スペクトルの評価結果 を図 14(a)に示す. 前章の BCJ-L2 の結果と同様に, 固有振動数 $\mathrm{f}_{0}$ を大 きくするに従い, $R_{1 \text { max }}$ は単調減少する. また, 表層地盤による加速 度増幅率の違いで, $\mathrm{f}_{0}$ によっては $\mathrm{R}_{1 \text { max }}$ は倍半分程度変化することが 確認できる. 簡略法(第 1 種地盤), 略算スペクトルにより求めた加 速度応答スペクトルに対しては, 殆じの $\mathrm{f}_{0}$ において $\mathrm{R}_{1 \max }$ が $1 / 20 \mathrm{rad}$ 以 下に収まっている，一方， $R_{1 \max }$ を $1 / 30 \mathrm{rad}$ に収めるためには簡略法(第 2 種地盤)では約 $4 \mathrm{~Hz}$ 以上, 略算スペクトルでは約 $4.5 \mathrm{~Hz}$ 以上必要で ある. 図 6 に示寸京町家のけた行方向の $\mathrm{f}_{0}$ は $4 \mathrm{~Hz}$ を下回る住宅が殆ど
であるため, 京町家のけた行方向の $\mathrm{R}_{1 \max }$ は $1 / 30 \mathrm{rad}$ を上回ると推察さ れる。

\section{（B）パルス性地震動}

パルス性地震動に対する最大応答変形の評価結果を図 14 (b) に示 す. JMA 神戸 $\mathrm{NS}$ は, $\mathrm{f}_{0}$ によらず $\mathrm{R}_{\max }$ が $1 / 15 \mathrm{rad}$ 程度であるが, $\mathrm{PGV}$ の 大きい鷹取 NS と JMA 川口 EW では，1/10 rad を大きく上回る $\mathrm{R}_{1_{\max }}$ にな ることが確認できる。鷹取 NS と JMA 川口 EW に対する $\mathrm{R}_{1 \text { max }}$ は JMA 神 戸NS と同様に $\mathrm{f}_{0}$ によらず概ね一定である。 その理由は, 鷹取 NS と JMA 川口EW の $S_{\mathrm{a}}-S_{d}$ は性能等価加速度応答スペクトル $S_{a e}-R * H_{e} / F_{h}$ との 交点の取る付近で $S_{d}$ が概䄈一定となるスペクトルの形状をしている ためであることが図 12(b)より分かる. また， $T_{p}$ の大きい刚羽村 NS で は， $\mathrm{f}_{0}$ が約 $4.5 \mathrm{~Hz}$ を境に $\mathrm{R}_{1 \text { max }}$ が大きく変化している.

(C) Ricker wavelet

Ricker wavelet の $\mathrm{T}_{\mathrm{p}}$ をJMA 神戸と同程度である $\mathrm{T}_{\mathrm{p}}=1 \mathrm{~s}$ で一定とし, $\mathrm{V}_{\mathrm{p}}=0.5,0.75,1.0 \mathrm{~m} / \mathrm{s}$ とした 3 波の $\mathrm{R}_{\mathrm{Imax}_{\text {max }}}$ の評価結果を図 $14(\mathrm{c})$ に示す. $\mathrm{T}_{\mathrm{p}}=1 \mathrm{~s}$ の場合, $V_{p}$ が一定であれば建物の固有振動数 $\mathrm{f}_{0}$ によらず $\mathrm{R}_{1 \text { max }}$ は概ね 一定となる. 次に, $V_{p}=0.75 \mathrm{~m} / \mathrm{s}$ で一定とし, $\mathrm{T}_{\mathrm{p}}=0.5,1.0,2.0 \mathrm{~s}$ とした 3 波

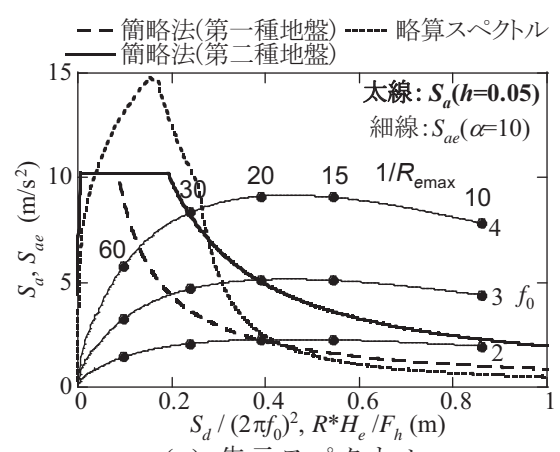

(a) 告示スペクトル

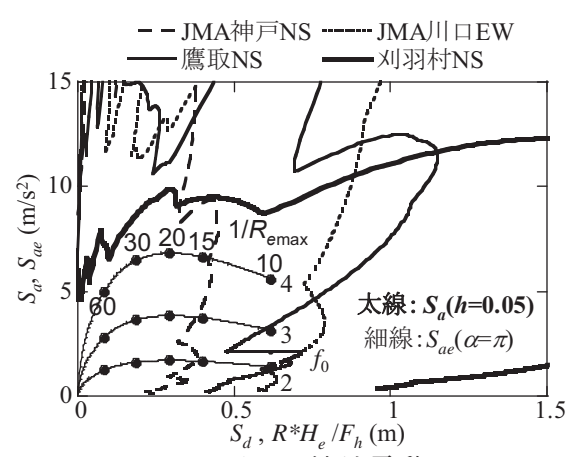

(b) パルス性地震動

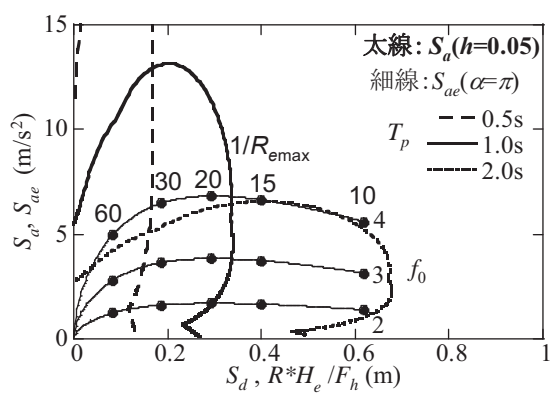

(c) Ricker wavelet $\mathrm{V}_{\mathrm{p}}=0.75 \mathrm{~m} / \mathrm{s}$

図12 $S_{a}-S_{d}$ 関係, $S_{a e}-R^{\star} H_{e} / F_{h}$ 関係 $\left[m_{2} / m_{1},=1, u_{2} / u_{1}=2, H_{1}=H_{2}=2.7 \mathrm{~m}, b=0.6\right]$

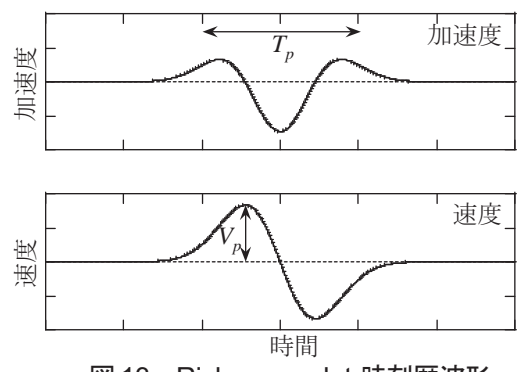

図 13 Ricker wavelet 時刻歴波形 (上: 加速度, 下: 速度)

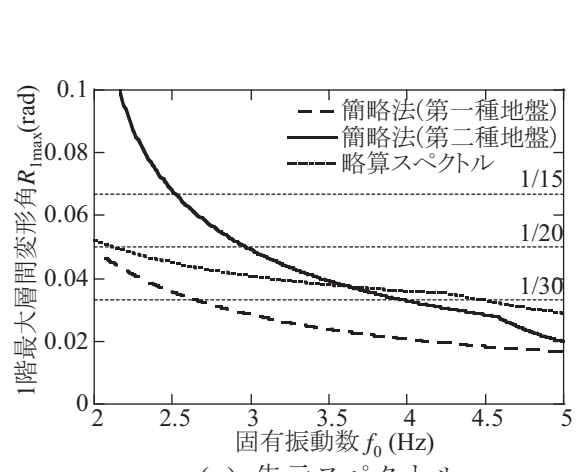

(a) 告示スペクトル

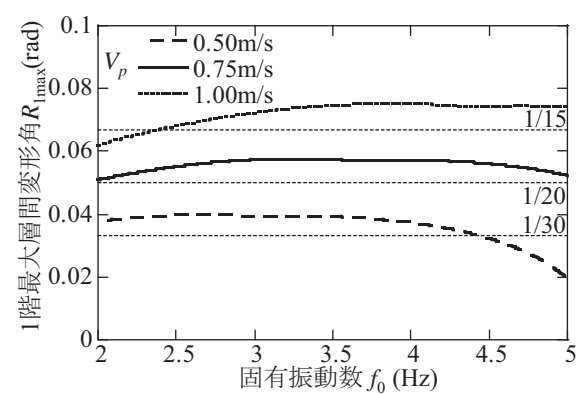

(c) Ricker wavelet $T_{p}=1.0 \mathrm{~s}$

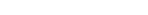

表 3 観測地震動のパルス特性値

\begin{tabular}{|c|c|c|}
\hline 略称 & $\begin{array}{c}\mathrm{T}_{p} \\
(\mathrm{~s})\end{array}$ & $\begin{array}{c}\mathrm{PGV} \\
(\mathrm{m} / \mathrm{s})\end{array}$ \\
\hline \hline JMA神戸NS & 0.9 & 0.86 \\
\hline 鷹取NS & 1.3 & 1.27 \\
\hline JMA川口EW & 1.3 & 1.35 \\
\hline 刈羽村NS & 3.0 & 1.22 \\
\hline
\end{tabular}

図 14 固有振動数 $f_{0} \Phi$ 建物

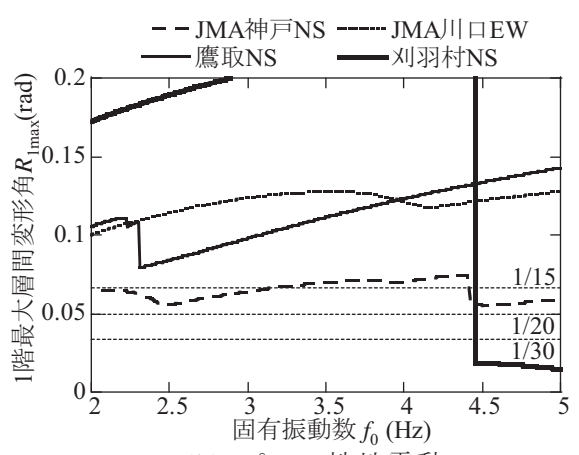

(b) パルス性地震動

(d) Ricker wavelet $\mathrm{V}_{\mathrm{p}}=0.75 \mathrm{~m} / \mathrm{s}$

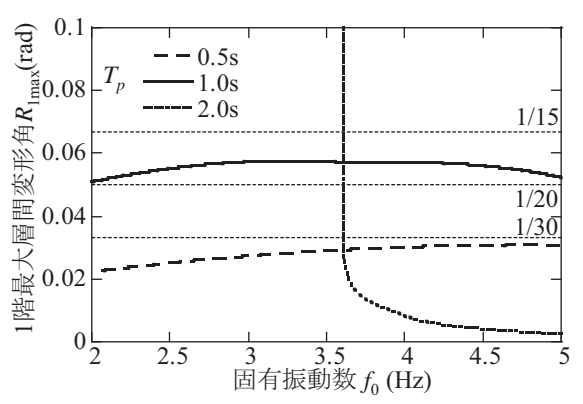
$\left[m_{2} / m_{1}=1, u_{2} / u_{1}=2, H_{1}=H_{2}=2.7 \mathrm{~m}, b=0.6\right]$ 
の $\mathrm{R}_{{ }_{\text {max }}}$ の評価結果を図 $14(\mathrm{~d})$ に示す. 同図より, $\mathrm{R}_{\mathrm{Imax}_{\max }}$ は $\mathrm{T}_{\mathrm{p}}=2.0 \mathrm{~s}$ になる と $\mathrm{f}_{0}$ によって $1 / 10 \mathrm{rad}$ を超えるほど変化が生じることが分かる.

\section{4 耐震対策の検討}

前項の 1 階最大層間変形角 $\mathrm{R}_{1 \max }$ の評価結果から, 伝統木造住宅の 耐震対策に関して以下のことが言える. 建築基準法告示で規定され る加速度応答スペクトルに対する住宅の $R_{1 \text { max }}$ は, $f_{0}$ が大きいほじ減 少する. よって, 住宅の耐力を増やすことで $\mathrm{R}_{1 \max }$ を低減することが できると考えられる。一方, パルス性地震動では, $\mathrm{f}_{0}$ が少々変化して

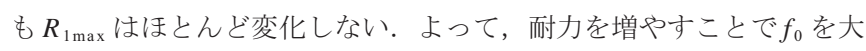
きくしても必ずしも $R_{1 \text { max }}$ の低減につながらないため, 変形性能を高 める耐震対策が必要となる.

\section{6. まとめ}

本論文では, 2 階建の伝統木造住宅を対象に, 常時微動計測に基づ く簡便な最大応答変形評価法を提案した。本論文で得られた成果・ 知見を以下に示す.

1) 伝統木造住宅の固有振動数の振幅依存性を表寸動的変形特性の評 価式を, 京町家の地震観測記録, 2 階建軸組架構の振動台実験, 全 壁を有する単位軸組架構の静的加力実験結果に基づいて構築し た. 動的変形特性評価式は, a) 常時微動計測から得た固有振動数, b) $1 / 1000 \mathrm{rad}$ での等価固有振動数の固有振動数からの低下率, c) 1 / $1000 \mathrm{rad}$ 以上での等価固有振動数の低下率, で表わされる. なお, 動的変形特性のばらつきを考虑できるような評価式のパラメータ を提案した。

2) 構築した動的変形特性の評価式を応答スペクトル法に適用するこ とで最大応答変形評価法を提案し, 既往の実大伝統木造住宅の震 動台実験結果を用いて評価法の精度検証を行った。

3) 本論文で提案した最大応答変形評価法を用いて, 入力地震動の加 速度応答スペクトルを変化させた場合の等価 1 自由度系モデルの 最大応答変形角を評価した結果, 耐震対策について以下の知見を 得た。

I) 建築基準法告示で規定される加速度応答スペクトルに対して は, 住宅の固有振動数が大きいほじ最大応答変形角は減少す る. よって, 耐力を増やすことで最大応答変形角を低減する ことができると考えられる。

II) パルス性地震動に対しては, 住宅の固有振動数が少々変化し ても最大応答変形角はほとんど変化しない. 従って, 耐力を 増やすことで固有振動数を大きくしても必ずしも最大応答変 形角の低減につながらないため, 変形性能を高めるような耐 震対策が必要となる.

本論文で提案した最大応答評価法は, 応答スペクトル法に立脚し ている，従って，限界耐力計算と同様に，a）偏心率が大きい場合，b) 床剛性が十分で無い場合, c) 最大応答変形が過大となる場合, d) 特 定層に変形が集中寸ることが㲘念される場合などには適用性に課題 が残る。そして, 本評価法は, 容易に実施可能な常時微動計測に基 づいて最大応答変形角を簡易に評価することを目的としているため, 各種パラメータの設定を簡便化している. そのため, 評価精度は高 いとは言い難いが，例えば，本評価法により詳細な耐震診断実施の 要否を迅速に判断することが可能となる. また, まとめの3)で示し た様に, 想定地震動に対する既存伝統木造住宅の最大応答変形角の
簡易予測, 耐震対策の決定などに資すると考えている.さらに, 強 震観測記録を用いた伝統木造住宅の被害原因の分析などにも有益で あると考えている.

\section{謝辞}

本研究は, 科学研究費補助金基盤研究(A)No.15H02275(代表者 : 林 康裕), 科学研究費補助金研究活動スタート支援No.15H06322(代表 者：杉野未奈)の補助の下で遂行した。試験体製作にあたり,(株)木 村工務店の木村忠紀棟梁に多大なご助力を頂いた. また, 防災科学 技術研究所, 気象庁, 鉄道総合技術研究所などが提供する観測地震 動や震動台実験結果を使用させていただいた。本研究の遂行には, 京都大学大学院工学研究科および同大学防災研究所の技術職員の皆 様, 同大学院工学研究科建築学専攻 建築保全再生学講座の大学院生 から多大な助力を頂いた。ここに記して謝意を表す.

\section{参考文献}

1) 木造軸組構法建物の耐震設計マニュアル編集委員会 : 伝統構法を生かす木造 耐震設計マニュアル - 限界耐力計算による耐震設計・耐震補強設計法, 2004.3.

2) 中川貴文, 佐藤弘美, 多幾山法子, 腰原幹雄, 林 康裕 : 2007 年能登半島地震にお ける木造住宅の被害の再現, 日本建築学会構造系論文集, 第78巻, No.688, pp.11131122, 2013.6.

3) 山辺克好, 金井清, 寺尾次夫 : 川崎市における木造家屋(2階建)の固有周期の測 定：日本建築学会大会学術講演梗概集, pp.501-502, 1977.10.

4) 田端千夏子, 大橋好光 : 微動測定とその耐震診断への応用の可能性 -木造建築 物の耐震診断法に関寸る研究その2-, 日本建築学会構造系論文集, No.616, pp.141-147, 2007.6.

5) 柳澤泰男, 田端千夏子, 大橋好光 : 既存木造軸組構法住宅の耐震性評価の精度 向上のための常時微動の活用に関寸る研究 - 実測值と理論值の関係- , 日本建 築学会技術報告集, 第17巻, No.37, pp.873-878, 2011.10.

6) (財)日本建築防災協会 : 木造住宅の而震診断と補強方法 (改訂版), 2004.7.

7) 岩本亮, 川瀬博, 包那仁満都拉 : 微動計測に基づいた在来木造住宅の振動特性 の地域性および年代変化, 日本建築学会構造系論文集, 第74巻, No.635, pp.3339, 2009.1.

8) 岡田成幸, 高井伸雄, 島田佳和: 微動のカオス性に着目した次元解析による木 造住宅の原位置的簡易耐震診断法の開発, 第12回日本地震工学シンポジウム 論文集, pp.1054-1057, 2006.11.

9) 新居藍子, 林康裕, 森井雄史, 井田祥子, 鈴木祥之 : 常時微動計測から推定され る京町家の振動性状, 日本建築学会構造系論文集, No.613, pp.43-50, 2007.3.

10) 杉野未奈, 多幾山法子, 大西良広, 林 康裕 : 固有振動数の振幅依存性に基づく 伝統木造建物の最大応答予測法, 日本建築学会構造系論文集, 第77巻, No.672, pp.197-203, 2012.2.

11) 林康裕 : 性能等価応答スペクトルに基づく建築物の地震荷重評価, 第11回日 本地震工学シンポジウム, pp.651-656, 2002.11.

12) 国土交通省住宅局建築指導課 他 : 2001年度版限界耐力計算法の計算例とそ の解説, 工学図書株式会社, 2001.3.

13) 森井雄史, 林康裕: 表層地盤の地震動増幅特性と入射地震動特性が木造建物 応答に及ぼす影響, 日本建築学会構造系論文集, No. 568, pp.75-82, 2003.6.

14) 鈴木恭平, 川辺秀憲, 山田真澄, 林康裕 : 断層近傍のパルス地震動特性を考慮 した設計用 応答スペクトル：日本建築学会構造系論文集, No.647, pp.49-56, 2010.1 .

15) 杉野未奈, 林康裕: 伝統木造軸組架構の仕様が復元力特性に及ぼす影響, 日本 建築学会技術報告集, Vol.21, 第47号, pp.113-118, 2015.2.

16) 南部恭広, 杉野未奈, 林康裕: 伝統木造住宅における耐力要素や重量の地域性 , 日本建築学会大会学術講演梗概集, 構造III, pp.195-196, 2015.9.

17) 大村早紀, 横部達也, 涉谷悦敬, 南部恭広, 杉野未奈, 林康裕: 土壁仕様の違いが 伝統木造軸組架構の構造特性に与える影響, 日本建築学会近畿支部研究報告 
集第55号構造系, pp.313-316, 2015.6.

18) (株)丸浩工業 : 荒壁パネル施工要領書, http://www.maruhiro.jp/product/sekou.pdf, 2015.11.30参照

19) 林康裕, 新居藍子, 森井雄史 : 木造軸組構法住宅の振動計測の活用に関する研 究, 日本地震工学会大会梗概集, pp.114-115, 2005.11.

20) 杉野未奈, 中西統也, 守屋友貴, 多幾山法子, 林康裕：パルス性地震動に対す る2階建伝統木造軸組架構の地震時挙動の把握と簡略応答評価, 日本建築学 会構造系論文集, 第79巻, No.700, pp.801-809, 2014.6.

21) 井田祥子, 森井雄史, 新居藍子, 林康裕 : 伝統的木造住宅の振動特性変化に基 づく構造ヘルスモニタリング, 日本建築学会近畿支部研究報告集 第48号 構 造系, pp.49-52, 2008.5.

22) 清水秀丸, 向坊恭介, 堀川恵巳子, 桘本敬大, 河合直人, 大橋好光 : 実大震動台 実験による伝統的な木造建物の耐震性能検証に関寸る研究-部材断面がやや 小さい都市近郊型試験体の震動台実験結果 : 日本建築学会構造系論文集, Vol.76, No.663, pp.943-950, 2011.5.

23) (財) 日本住宅・木材技術センター : 伝統的木造軸組構法住宅の耐震性能検証 実験報告書, 2009.3

24) 清水秀丸, 向坊恭介, 堀川恵巳子, 槌本敬大, 河合直人, 大橋好光 : 実大震動台 実験による伝統的な木造建物の耐震性能検証に関する研究-部材断面が大き な地方型試験体の震動台実験結果: 日本建築学会構造系論文集, Vol.75, No.657, pp.2001-2008, 2010.11

25) 小笠原昌敏, 鈴木祥之, 林秀春, 小嶋伸仁, 清水秀丸, 中村いずみ : 新築京町家 の実大振動台実験による耐震性能評価 : 第12回日本地震工学シンポジウム
論文集, pp.798-801, 2006.11.

26）向坊恭介, 鈴木祥之, 鎌田輝男, 具典淑, 川上沢馬 : 京町家の実大振動台実験に よる地震応答特性の分析 : 第12回日本地震工学シンポジウム論文集, pp.770$773,2006.11$.

27) 京町家震動台実験研究会 : 京町家の而震補強と新しい京町家をつくる, 2006.7.

28) 土塗壁等告示に係る技術解説書作成編集委員会 : 土塗壁・面格子壁・落とし 込み板壁の壁倍率に係る技術解説書，（財）日本住宅・木材技術センター, 2004.2 .

29) 一般財団法人 日本建築センター, http://www.bcj.or.jp/download/wave.html, 2015.11.30参照

30) 気象庁: 強震波形（平成7年(1995年)兵庫県南部地震）, http://www.data.jma.go.jp/svd/eqev/data/kyoshin/jishin/hyogo_nanbu/index.html, 2016.07.01参照

31) E-ディフェンスアーカイブ(ASEBI), https://www.edgrid.jp/, 2015.11.30参照

32) 林康裕, 森井雄史, 鬼丸貞友, 吉川正隆 : 限界耐力計算法における地盤増幅係 数評価に関する研究, 日本建築学会構造系論文集, No. 567, pp. 41-46, 2003.5.

33) 南 博之, 林康裕 : パルス波地動を受けるせん断弾性棒の応答特性評価, 日本 建築学会構造系論文集, 第78巻, No.685, pp.453-460, 2013.3.

34) 杉野未奈, 大村早紀, 林康裕: 常時微動計測に基づく伝統木造建物の最大応答 変形評価, 日本建築学会近畿支部研究報告集 第55号構造系, pp.333-336, 2015.6.

35) 杉野未奈, 徳岡怜美, 大村早紀, 林康裕: 常時微動計測による伝統木造建物の 最大応答変形評価その 1,2 , 日本建築学会大会学術講演梗概集, 構造III, pp.475478, 2015.9. 


\title{
MAXIMUM RESPONSE EVALUATION OF TRADITIONAL WOODEN HOUSES BASED ON MICROTREMOR MEASUREMENTS
}

\author{
Mina SUGINO*, Saki OHMURA**, Satomi TOKUOKA** \\ and Yasuhiro HAYASHI*** \\ * Assist. Prof., Dept. of Architecture and Architectural Eng., Kyoto Univ., Dr.Eng. \\ ** Grad. Stud., Dept. of Architecture and Architectural Eng., Kyoto Univ. \\ *** Prof., Dept. of Architecture and Architectural Eng., Kyoto Univ., Dr.Eng.
}

There are many traditional wooden houses forming historical townscapes in Japan. Microtremor measurements can be useful to evaluate seismic performance of these houses easily because microtremor measurements is conducted in a short time without any destruction. Although several researches estimate seismic capacity grade or yield base shear coefficient of houses based on the natural frequency which is obtained from microtremor measurements, these researches do not evaluate the maximum response deformation angle of houses against earthquake ground motions.

In our previous study, we have proposed the amplitude dependency of vibration characteristics such as natural frequency and damping ratio based on shaking table tests of wooden frame specimens. Applying this amplitude dependency of vibration characteristics into response spectrum method, the maximum response deformation angle of wooden frame specimens against an input wave has been estimated approximately. In this paper, we develop the amplitude dependency of natural frequency which can be applicable for existing traditional wooden houses and establish the maximum response deformation angle evaluation method using microtremor measurements and the amplitude dependency of natural frequency.

In this study, response spectrum method is used to evaluate the maximum response deformation angle. First, a traditional wooden house is modeled into the two degree of freedom model. The two degree of freedom model is converted into the equivalent single degree of freedom model. The maximum response deformation angle is evaluated from the intersection of a predicted acceleration response spectrum and the equivalent response spectrum. The equivalent response spectrum is calculated from the natural frequency and the amplitude dependency of natural frequency which is proposed in this paper.

The amplitude dependency of natural frequency is expressed as the ratio of the equivalent natural frequency of traditional wooden houses to the natural frequency. Equation of the amplitude dependency of natural frequency is established based on the results of seismic observation of three wooden houses in Kyoto, shaking table tests of two-storied traditional wooden frame specimens and static lateral loading tests of full wall specimens. The equation of the amplitude dependency of natural frequency consists of three elements: a) the natural frequency, b) the ratio of the equivalent natural frequency at 1/1000rad to the natural frequency and c) the ratio of the equivalent natural frequency at more than 1/1000rad to the equivalent natural frequency at 1/1000rad.

To confirm the accuracy of the proposed maximum response deformation angle evaluation method, the maximum response deformation angle on the first story of the full scale specimens of shaking table tests is evaluated. As an application example, simulation analysis using this proposed evaluation method is conducted against several acceleration response spectra changing the natural frequency of houses. The major findings from the simulation analysis are summarized as follows.

1) The maximum response deformation angle on the first story decreases as the natural frequency of houses increases in case of design spectra in Japan. Therefore, it is effective to increase walls and strengthen houses against design spectra in Japan.

2) In case of pulse-like ground motions, the maximum response deformation angle on the first story do not change so much by the natural frequency. Therefore, it is important to increase deformation capacity of houses against pulse-like ground motions. 